\title{
КІНЕТИКА ТА ЕНЕРГЕТИКА ПРОЦЕСІВ ЕКСТРАГУВАННЯ 3 ДЕРЕВИНИ ДУБА В ЕЛЕКТРОМАГНІТНОМУ ПОЛІ
}

\author{
Акімов О.В., аспірант, Молчанов М.Ю., магістр, \\ Войтенко О.К., канд. техн. наук, доцент, \\ Бурдо О.Г. проф., д-р. техн. наук, професор \\ Одеська національна академія харчових технологій, м. Одеса
}

У статті розглянутий новий перспективний метод екстрагування з використанням електромагнітних технологій. Надані переваги методу екстрагування у електромагнітному полі перед традиційним методами.

Головною проблемою традииійних технологій є неповнота вилучення иільових компонентів та тривалість прочесу екстрагування. Розглянуто можливості та перспективи використання дубових екстрактів у різних галузях промисловості. Сформульовано головне науково-технічне протиріччя процесу екстрагування. Запропонована гіпотеза екстрагування у електромагнітному полі.

Приводиться методика дослідження та детальний опис установок, на яких проводилися експериментальні дослідження. Приведені параметри, при яких проводилися експериментальні дослідження. Представлені порівняння термограм, зміни коефіцієнтів світлопропускання та витрат електроенергії n'ятьох серій експериментів, де екстрагентом виступала вода, проведено їх аналіз. Представлені дані щодо концентрації сухих речовин у отриманих екстрактах.

Проведено серію експериментальних дослідження з екстрагування дубової деревини етиловим спиртом, представлені термограми процесів та зміни коефіцієнта світлопропускання. Проведено порівняння концентрації сухих речовин у отриманих екстрактах.

Запропонована інноваційна технологія отримання високоекстарктивних вин з використанням МХ технологій та дубової деревини, як альтернатива витримки в дубових бочках. Дана коротка органолептична характеристика отриманих екстрактів та високоекстрактивних вин.

Доведена гіпотеза о можливості отримання поліекстрактів при використанні розчинника із полярними молекулами та в умовах мікрохвильового поля. Підтверджено дію механодифузійного ефекту. Визначено, щуо вихід цільових компонентів у МХ екстракторах в 2,5...5 разів вищий, ніж у традиційних при знижені енергетичних витрат у 1,5...2 рази.

Визначено, що найбільш привабливими є плівкові та циркуляційні екстрактори, вони мають переваги щуодо отримання якісних поліекстрактів з дубової деревини, з більш повним вилученням компонентів та перспективами промислового впровадження.

Ключові слова: екстрагування, електромагнітне поле, кінетика, енергетика, дубова деревина.

Вступ

Перспективним методом отримання екстрактів з рослинної сировини у різних галузях промисловості $\epsilon$ використання електромагнітних технологій. Такі технології активно вивчаються. Однією з переваг електромагнітних технологій перед традиційними $є$ те, що процес може проводитись при більш низьких температурах, що виключає деградацію термолабільних компонентів сировини та дозволяє суттєво скоротити тривалість процесу екстрагування. А використання в якості екстрагенту полярних розчинників дозволяє вилучити такі компоненти, які традиційні технології без використання додаткових етапів підготовки сировини не здатні.

Аналіз літературних джерел та формулювання проблеми

В промисловості екстрагування є одним з головних технологічних процесів переробки сировини. А повнота вилучення цільових компонентів та тривалість процесу - є ключовими факторами, що впливають на якість кінцевих екстрактів, витрати енергії, та економічні показники. Традиційні технології отримання екстрактів не можуть задовольнити ці потреби. Як відомо, вплив високих температур погіршує смак і аромат продуктів, сприяє окисленню або руйнування біологічно активних речовин, таких як вітаміни, поліненасичені жирні кислоти, пігменти [1]. А екстрагування за традиційними методами проводиться при відносно високих температурах, які можуть спричинити руйнування цільових компонентів сировини. Значна тривалість процесу екстрагування сприяє підвищеним витратам електроенергії та коштів на процес виробництва екстрактів. Неповнота вилучення цільових компонентів з сировини і неповна переробка вторинної сировини негативно впливає на довкілля та економічні показники. 
Значимість процесу екстрагування пояснюється його здатністю забезпечити практично вичерпне вилучення екстрагованих речовин при невисокій температурі, що є запорукою отримання витягів високої якості. Тому, в промисловість поступово почали впроваджувати електрофізичні методи обробки харчових продуктів: струми ВЧ і НВЧ, електростатичне поле, ультразвук, інфрачервоне випромінювання, струми промислової частоти та ін. Використання цих способів в технологіях переробки сировини дозволяє скоротити тривалість теплової обробки, забезпечити раціональні температурні режими, знизити питомі витрати енергії, що в свою чергу підвищує якість продукції і дає значний економічний ефект [2]. Серед вищезазначених способів, особливу популярність поступово набирає надвисокочастотна (НВЧ) енергетика, яка знайшла широке застосування в різних галузях виробництва, що обумовлено іiі високою ефективністю і розвитком виробництва промислових генераторів різної потужності [3]. Важливим фактором поступового переходу на використання НВЧ обробки в харчовій промисловості є перехід людства на здорове і функціональне харчування, обізнаність людства про користь споживання повноцінної і здорової їжі, споживання більшої кількості вітамінів, мінералів, антиоксидантів з продуктами харчування[4]. У зв'язку з цим розробляються і поліпшуються нові методи отримання екстрактів, які дозволяють максимально витягти всі необхідні компоненти, а також будуть екологічними.

У зв'язку із зростанням попиту на екстракти з рослинної сировини, орієнтир на здорове харчування, необхідність задовольнити харчову, фармацевтичну, косметичну, парфумерну і хімічну галузі потрібні все більші обсяги виробництва екстрактів, потрібно прискорити процес екстрагування. Традиційні методи не дозволяють в повній мірі задовольнити запити сучасного виробництва, неповнота вилучення компонентів рослинної сировини та екологічна ситуація, що склалася, ставить досить актуальною проблему дбайливого та повного використання рослинної сировини, а це, в свою чергу, підштовхує на розробку нових, більш продуктивних та енергоефеткивних методів отримання екстрактів [5 - 9].

У сучасній технології фітопрепаратів відомі так звані поліекстракти (поліфракційний екстракти) препарати, які отримують з лікарської рослинної сировини декількома розчинниками послідовною екстракцією, наприклад, зі зростаючою полярністю [10].

Екстракти з дубової деревини використовуються в різних галузях промисловості: харчовій, виноробній, фармацевтичній та парфумерній. Особливу привабливість дані екстракти можуть представляти для фармацевтичної та косметичної промисловості, а також, в перспективі, для виноробної промисловості для виробництва високоекстрактивних вин, як альтернатива витримки в дубових бочках або на дубових чіпсах, та виробництва коньяків за прискореним методом. В якості використання у медицині дубовий екстракт проявляє антисептичну, протиалергійну і протизапальну дію, $є$ антиоксидантом.

\section{Науково-технічне протиріччя процесу екстрагування}

Таким чином, температура процесу екстрагування є ключовим фактором. 3 одного боку - підвищення температури позитивно впливає на продуктивність екстрактора. 3 іншого боку підвищення температури негативно впливає на збереження цільових компонентів. У відходах різних галузях харчової промисловості залишається істотна частина функціональних компонентів, комерційна цінність яких часто перевищує вартість готового продукту. Тому, основним, ставиться завдання знайти рішення цих протиріч, отримати кінетичні на енергетичні залежності при екстрагуванні дубової деревини в умовах використання електромагнітного поля.

\section{Гіпотеза дослідження}

Основною науково-технічною гіпотезою екстрагування у електромагнітному полі є те, що використання у якості екстрагенту полярних розчинників та використання адресної доставки енергії дозволить здійснити вихід цільових компонентів з рослинної сировини у вигляді двох потоків: традиційного дифузійного, який $є$ дуже повільним і залежить від багатьох факторів, на які складно впливати, і другого - гідродинамічного, який потужніший за дифузійний, і яким можна управляти та прискорювати. Гідродинамічний потік дозволить забезпечити вихід більшої кількості компонентів, як розчинних і слаборозчинних так і нерозчинних, що дозволить отримати поліекстракти.

\section{Експериментальне моделювання та методика дослідження}

Для проведення експерименту в якості сировини використовували дубову деревину у виді кубиків розміром приблизно 2 на 2 см, термічно оброблених. Термічна обробка проводилася для кращого вилучення екстрактивних речовин з дубової деревини. В якості екстрагенту використовували дистильовану воду та етанол. Експерименти проводилися на чотирьох екстракційних установках. Експериментальне моделювання екстрагування за традиційним методом проводилося на водяній бані. Схеми установок, що моделюють інноваційні методи представлені на рис. 1-3. Замір температури проводився пірометром (FLIR TG54), витрати енергії вимірювалися електронним лічильником (Енергометр TM55), визначення коефіцієнту світлопропускання спектрофотометром (Spekol). Концентрацію сухих речовин отримували методом висушування певного об'єму отриманих екстрактів у сушильній шафі, замір ваги проводився на аналітичних електронних вагах високої точності. 


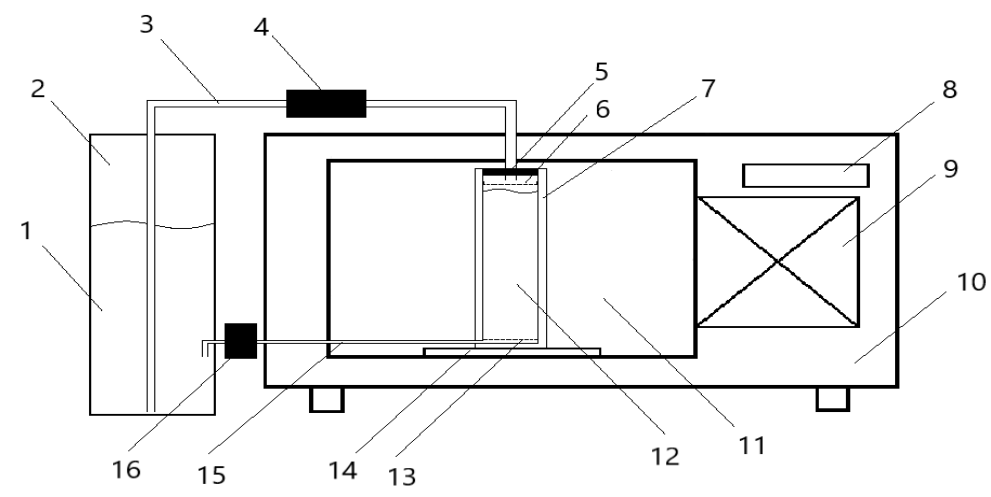

Рис. 1 - Плівковий МХ екстрактор

Плівковий МХ екстрактор складається з таких елементів: 1 - екстрагент; 2 - ємність для екстрагента; 3 підвідний патрубок; 4 -насос; 5 - кришка реактора; 6 - пристрій для розпилення; 7 - реактор; 8 - пульт керування; 9 - магнетрон; 10 - корпус; 11 - мікрохвильова камера; 12 - сировина; 13 - фільтрувальна сітка; 14 - підставка; 15 - відвідний патрубок; 16 - кран.

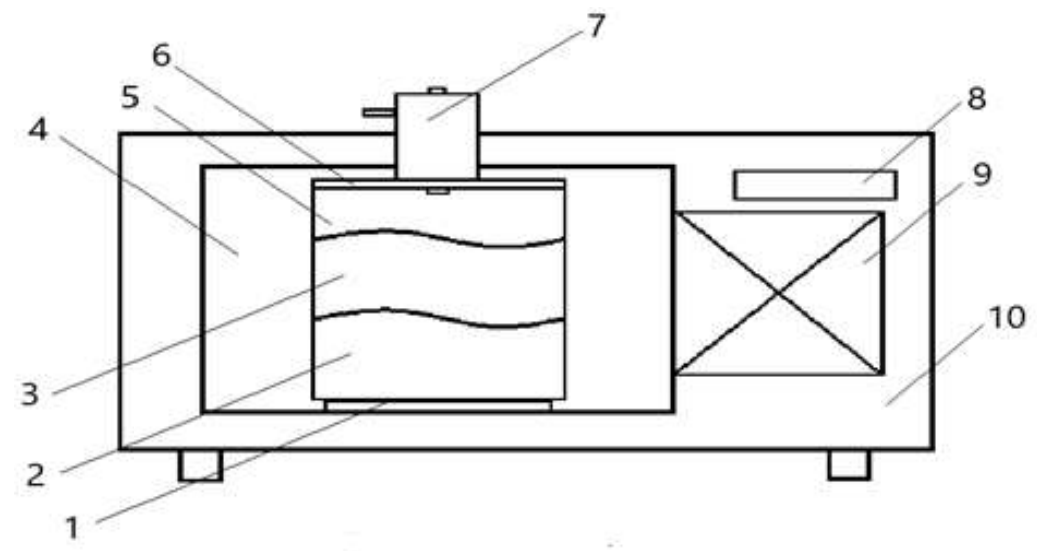

Рис. 2 - Вакуумний МХ екстрактор

Вакуумний МХ екстрактор складається з таких компонентів: 1 - підставка; 2 - сировина; 3 - екстрагент; 4 - мікрохвильова камера; 5 - ємність; 6 - кришка ємності; 7 - зворотний холодильник; 8 - пульт керування; 9 - магнетрон; 10 - корпус. Даний екстрактор дозволяе працювати як при вакуумі, так і проводити процес при атмосферному тиску.

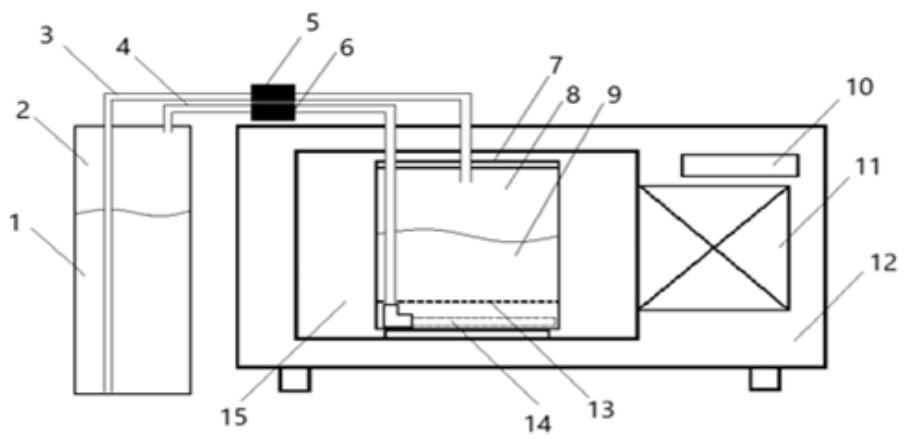

Рис. 3 - Циркуляційний МХ екстрактор

Основними вузлами циркуляційного МХ екстрактора $є: 1$ - екстрагент; 2 - ємність для екстрагенту; 3 підвідний патрубок; 4 - відвідний патрубок; 5 - підвідний насос; ; 6 - відкачуючий насос; 7 - кришка; 8 ємність для сировини; 9 - сировина; 10 - пульт керування; 11 - магнетрон; 12 - корпус; 13 -перфорована тефлонова підставка; 14 - фільтр; 15 - мікрохвильова камера.

Всього було проведено 5 серій експериментальних досліджень з екстрагування дубової деревини водою на чотирьох екстракційних установках та 6 серій експериментальні дослідження з екстрагування дубової деревини етиловим спиртом та червоним вином міцністю $10 \%$ об. Параметри експериментальних досліджень представлені в таблищі 1 . 
Параметри процесу екстрагування

\begin{tabular}{|c|c|c|c|c|c|c|c|c|}
\hline $\begin{array}{l}\text { № } \\
\text { ce- } \\
\text { piii. }\end{array}$ & Екстрактор & $\begin{array}{c}\text { Мaca } \\
\text { дере- } \\
\text { вини, г }\end{array}$ & $\begin{array}{c}\text { Екстра- } \\
\text { гент }\end{array}$ & $\begin{array}{c}\text { Маса } \\
\text { екстра- } \\
\text { генту, г }\end{array}$ & $\begin{array}{c}\text { Тиск, } \\
\text { кПа }\end{array}$ & $\begin{array}{l}\text { Темпера- } \\
\text { тура про- } \\
\text { цесу, }{ }^{\circ} \mathrm{C}\end{array}$ & $\begin{array}{l}\text { Встанов- } \\
\text { лена поту- } \\
\text { жність, Вт }\end{array}$ & $\begin{array}{l}\text { Трива- } \\
\text { лість, хв }\end{array}$ \\
\hline 1 & Водяна баня (ВБ) & 100 & вода & 500 & 100 & до 50 & & 300 \\
\hline 2 & $\begin{array}{l}\text { Плівковий МХ екс- } \\
\text { трактор (ПМХЕ) }\end{array}$ & 100 & вода & 500 & 100. & до 55 & 127 & 90 \\
\hline 3 & $\begin{array}{l}\text { Вакуумний MX } \\
\text { екстрактор (BMXE) }\end{array}$ & 100 & вода & 500 & 15 & до 55 & 127 & 30 \\
\hline 4 & $\begin{array}{l}\text { MX екстрактор } \\
\text { (MXE) }\end{array}$ & 100 & вода & 500 & 100. & до 55 & 127 & 30 \\
\hline 5 & $\begin{array}{l}\text { Циркуляційний МХ } \\
\text { екстрактор (ЦМХЕ) }\end{array}$ & 100 & вода & 500 & 100 & до 55 & 200 & 50 \\
\hline 6 & $\begin{array}{l}\text { Плівковий МХ екс- } \\
\text { трактор (ПМХЕ) }\end{array}$ & 140 & $\begin{array}{c}\text { етиловий } \\
\text { спирт }\end{array}$ & 420 & 100 & до 60 & 255 & 16 \\
\hline 7 & $\begin{array}{l}\text { Циркуляційний МХ } \\
\text { екстрактор (ЦМХЕ) }\end{array}$ & 180 & $\begin{array}{l}\text { етиловий } \\
\text { спирт }\end{array}$ & 540 & 100 & до 50 & 255 & 16 \\
\hline 8 & $\begin{array}{l}\text { Циркуляційний МX } \\
\text { екстрактор (ЦМХЕ) }\end{array}$ & 180 & $\begin{array}{c}\text { етиловий } \\
\text { спирт } 72 \% \\
\end{array}$ & 540 & 100 & до 55 & 255 & 20 \\
\hline 9 & $\begin{array}{l}\text { Плівковий МХ екс- } \\
\text { трактор (ПМХЕ) }\end{array}$ & 100 & $\begin{array}{c}\text { червоне } \\
\text { вино } \\
\end{array}$ & 500 & 100 & до 40 & 127 & 36 \\
\hline 10 & $\begin{array}{l}\text { Плівковий МХ екс- } \\
\text { трактор (ПМХЕ) }\end{array}$ & 100 & $\begin{array}{c}\text { червоне } \\
\text { вино }\end{array}$ & 500 & 100 & до 40 & 127 & 18 \\
\hline 11 & $\begin{array}{l}\text { Вакуумний MX } \\
\text { екстрактор (BMXЕ) }\end{array}$ & 100 & $\begin{array}{l}\text { червоне } \\
\text { вино }\end{array}$ & 500 & 100 & до 40 & 127 & 28 \\
\hline
\end{tabular}

Результати експериментальних досліджень та їх обговорення. В ході проведення експериментів 3 екстрагування дубових кубиків водою були отримані наступні дані: термограми процесів екстрагування (рис. 5), зміна коефіцієнту світлопропускання (рис. 6), витрати енергії (рис. 7). Термограма процесів екстрагування усіх п’ятьох серій експериментів представлена на рис.5.

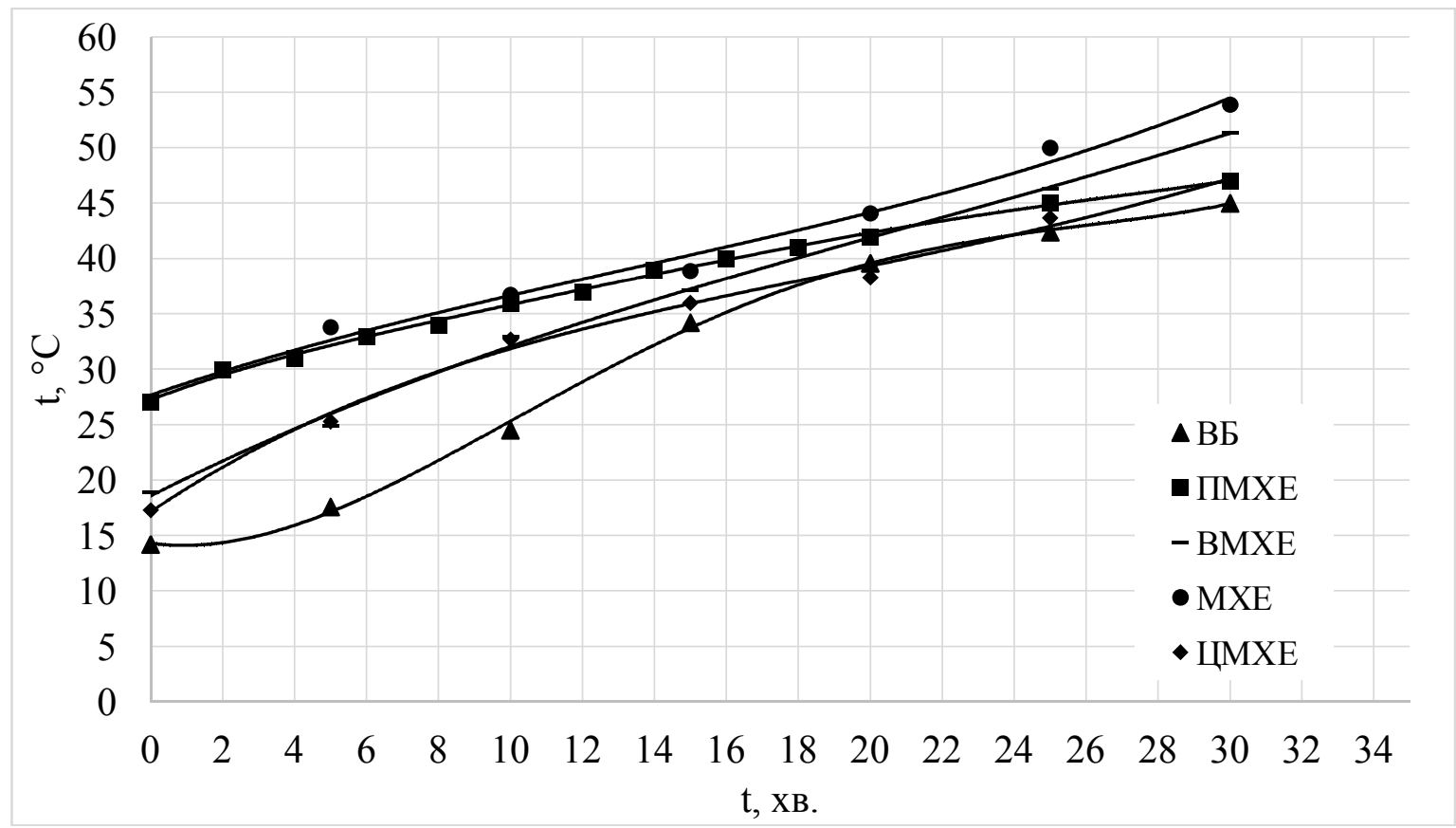

Рис. 5 - Порівняння термограм процесів при екстрагуванні водою

Данні (рис.5) свідчать, що темпи зростання температури найнижчі у ЦМХЕ, незважаючи на те, що в цих дослідах була встановлена найбільша потужність магнетронів. Тобто, в такій конструкції ефективність використання енергії вища, вірогідність організації потужних механодифузійних процесів більш очікувана. За циркуляційними по ефективності використані енергії визначились плівкові екстрактори. Взагалі, в усіх конструкціях екстрагування проводилось у м'яких режимах. 


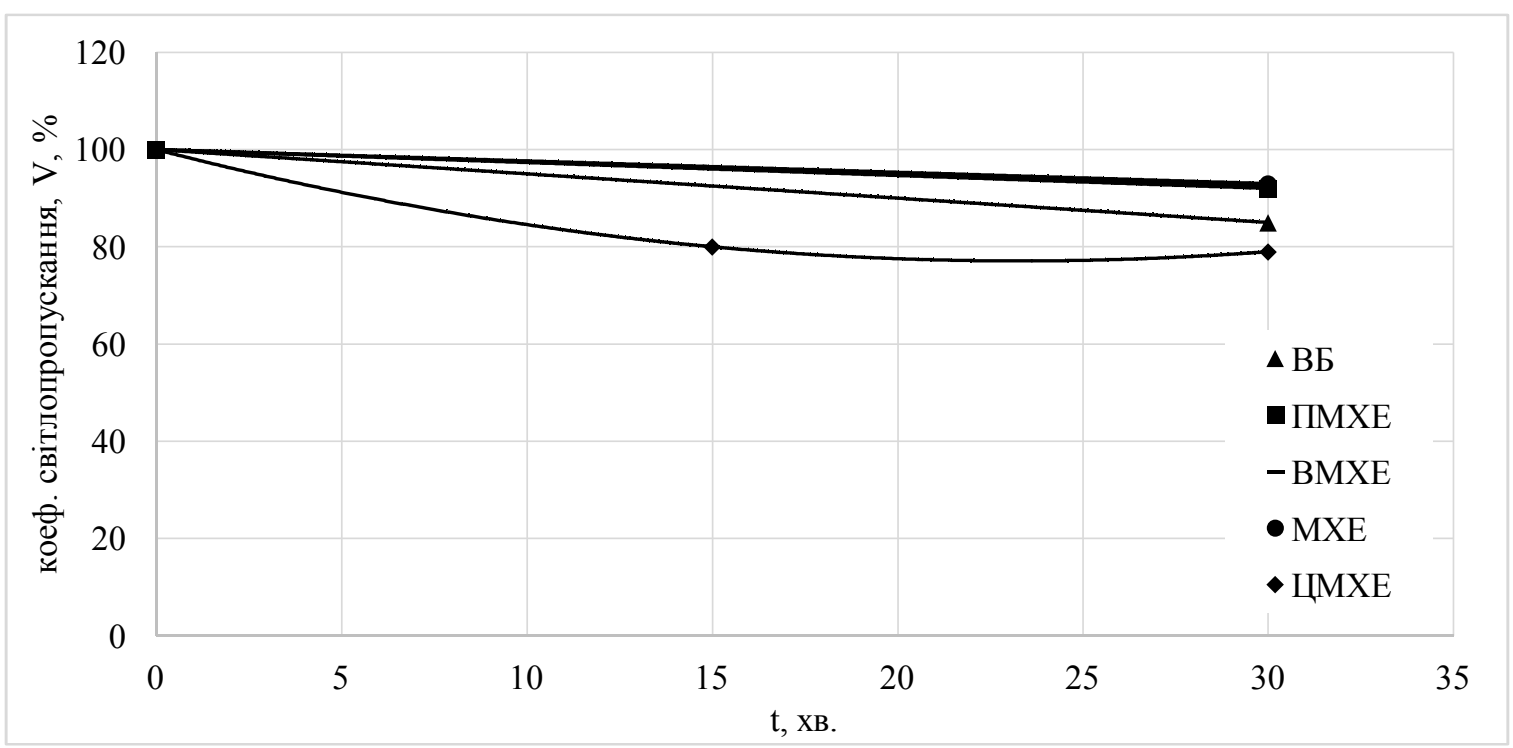

Рис. 6 - Кінетика масоперенесення за коефіціснтом світлопропускання

Висновок із (рис.5), що у циркуляційному екстракторі повинен бути найбільш потужний механодифузійний потік підтверджує аналіз рис.6. Саме у цій конструкції визначився самий низький коефіцієнт світлопропускання. Занурення кубиків у об’єм екстракту блокувало організацію механодифузійних процесів. Ці процеси характеризувались низькими показниками коефіцієнту світлопропускання. Так, для ВМХЕ та МХЕ вони становлять - 92,5 \% та 93 \% відповідно рис. 6, що свідчить про те, що у екстрагент 3 дубової деревини перейшла дуже мала кількість екстрактивних компонентів. Отримані екстракти мали дуже слабий аромат дубової деревини та майже не мали забарвлення.

Експеримент на водяній бані мав високу тривалість процесу - 5 годин, при цьому коефіцієнт світло пропускання становив 75 \%, що значно краще за два попередні зразки. Після 60 хвилин температура процесу перейшла в усталений режим і практично не змінювалася. Не дивлячись на відносно високий показник коефіцієнту світлопропускання даний метод є дуже тривалим, що є економічно невигідним. Отриманий екстракт мав ярко виражений аромат дубової деревини і світло-коричневе забарвлення.

Що стосується циркуляційного екстрактору, то в нього найкращі показники по коефіцієнту світлопропускання у кінцевому зразку екстракту - 74 \%. Отриманий екстракт мав ярко виражений, характерний аромат дубової деревини та світло-коричневе забарвлення, схоже на слабо заварений чорний чай. Наступним етапом аналізу є енергетика процесів (рис.7)

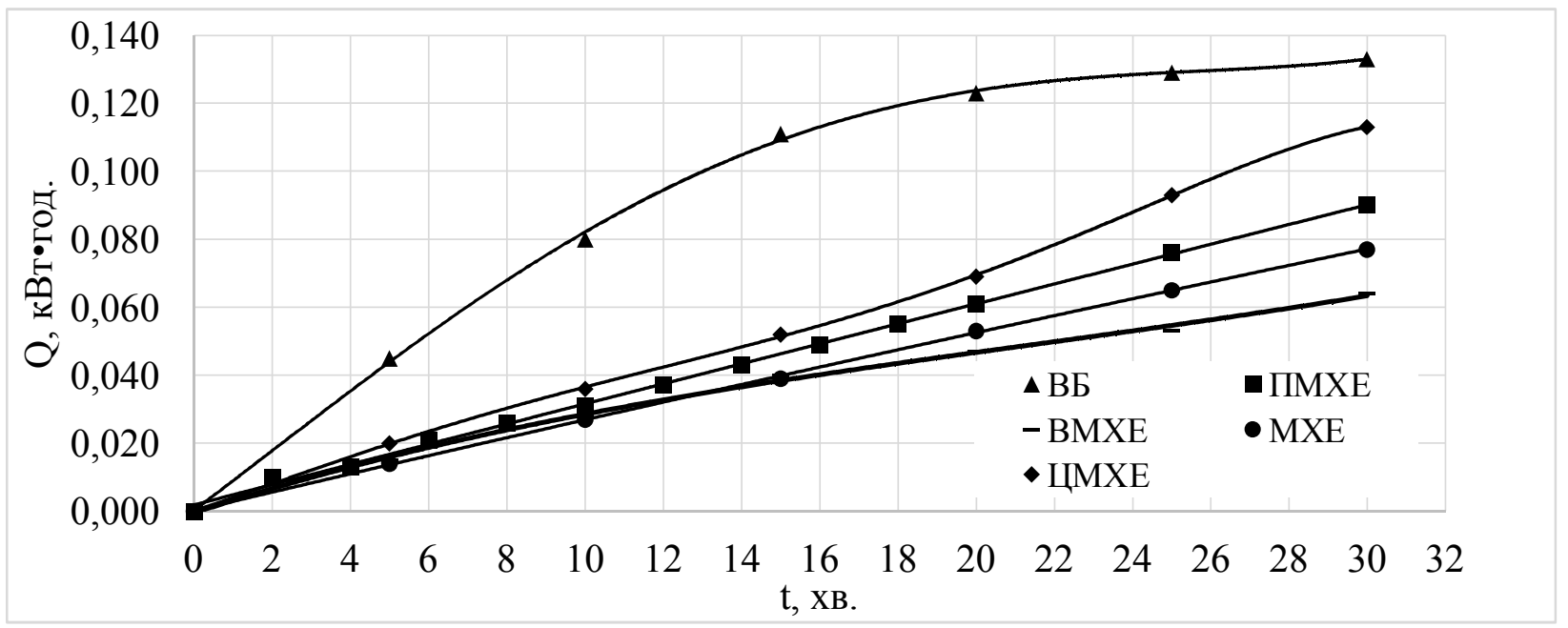

Рис. 7 - Порівняння витрат енергії

Аналіз (рис. 7) показує, що апарати із МХ генераторами мають значно нижчі витрати енергії, ніж традиційні екстрактори. Найнижчі затрати електроенергії у ВМХЕ та МХЕ. Більш високі затрати електроенергії у ПМХЕ та ЦМХЕ можна пояснити тим, що крім магнетрону, в установках додатково працюють насоси: 1 
насос у ПМХЕ та 2 насоси у ЦМХЕ. Більш за те, конструкція циркуляційного екстрактору мала потужність майже вдвічі більшу.

Таким чином, для порівняння конструкцій із МX генераторами, процеси в яких відрізнялись гідромодулем, масою твердої фази, потужністю магнетронів необхідно запропонувати загальний питомий показник, який дозволив би визначити їх ефективність. За такий показник пропонується прийняти відношення маси вилучених із твердої фази цільових компонентів до одиниці розчину у одиницю часу (рис.8).

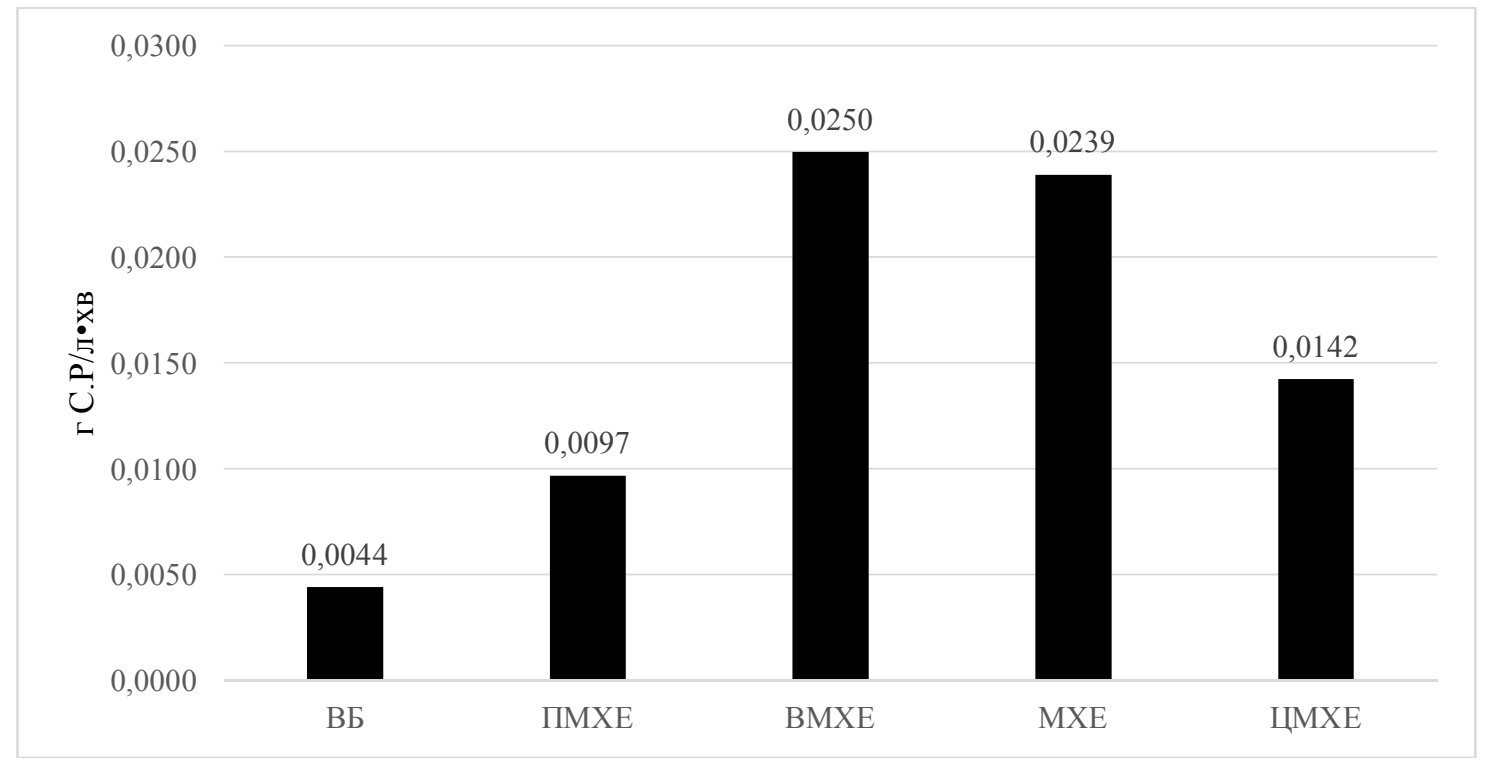

Рис. 8 - Питомі показники ефективності екстракторів

Аналіз рис.8 показує, що показники ефективності МХ екстракторів у рази перевищують ефективність традиційних конструкцій. Екстракти отримані у циркуляційних екстракторах відрізняються ярко вираженим, характерним ароматом дубової деревини та темно-коричневим кольором, кольором міцно завареного чорного чаю.

В серіях дослідів 6 - 8 (табл.1) проводилося екстрагування дубової деревини етиловим спиртом міцністю 62 об.,\%, (в екстракторах ПМХЕ та ЦМХЕ) та 72 об.\% (в екстракторі ЦМХЕ). Температури процесу у ПМХЕ дещо вищи за температури у ЦМХЕ екстракторі (рис. 9), імовірно, це пов'язано з тим, що гідромодуль ЦМХЕ вищий за гідромодуль ПМХЕ.

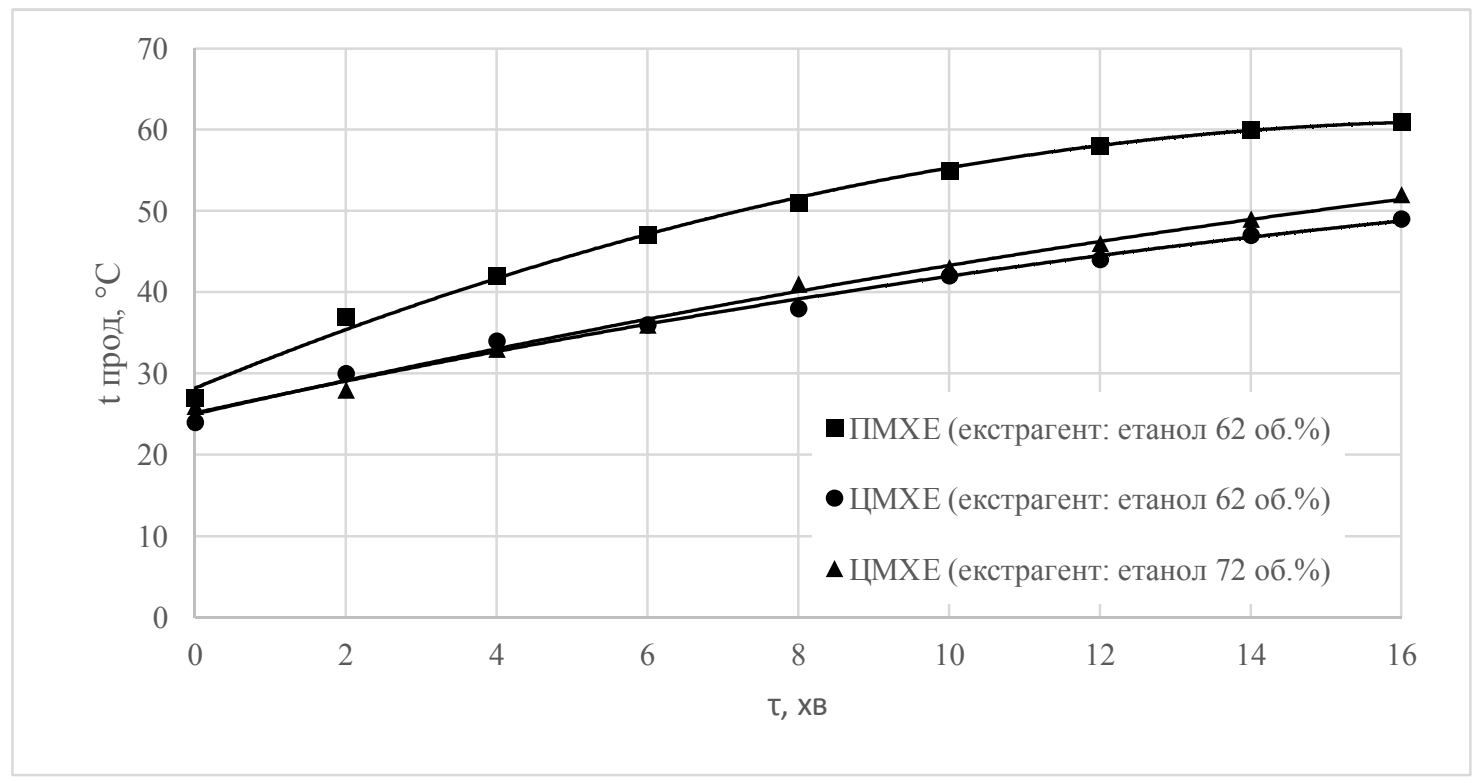

Рис. 9 - Термограми процесів екстрагування етанолом

Кінцеве значення сухих речовин у екстракті становить 3 г/л, що суттєво вище за попередні показники. Показники сухих речовин кінцевих екстрактів представлені на рис. 10. 


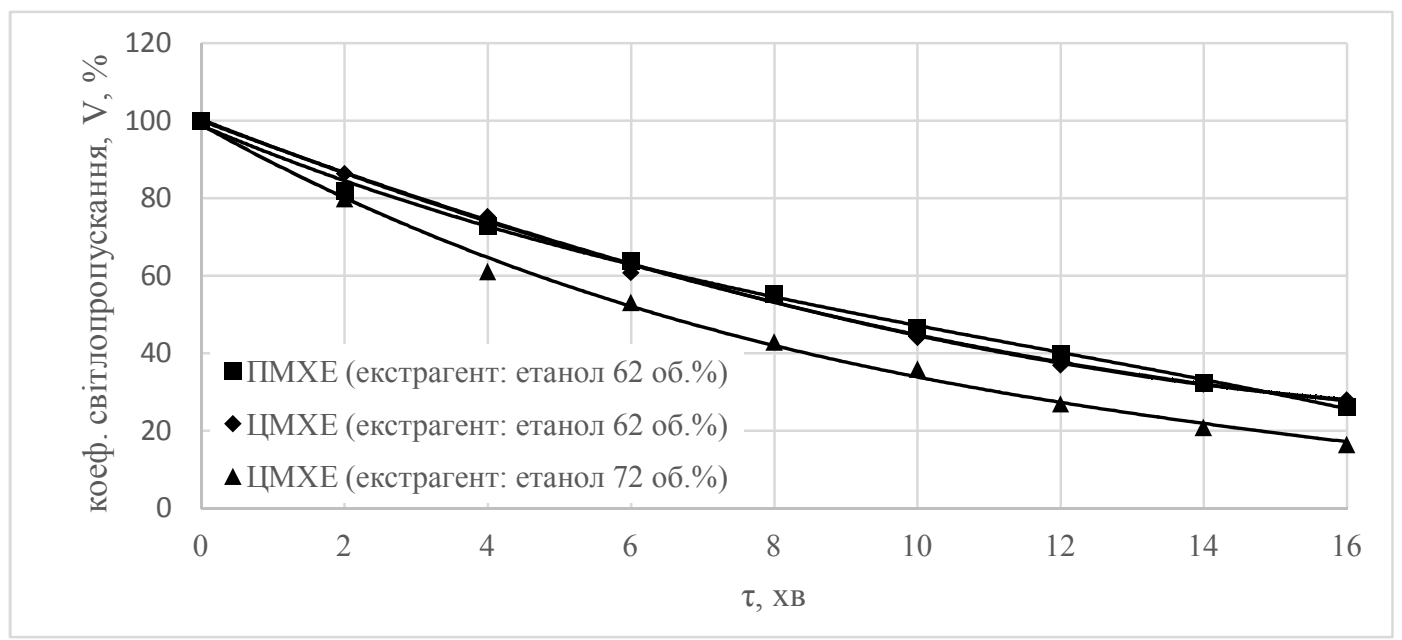

Рис. 10 - Порівняння зміни коефіцієнту світлопропускання

Отримані дані щодо зміни коефіцієнту світлопропускання (рис. 10) під час екстрагування етиловим спиртом свідчать про те, що за однаковий період часу, при однаковій потужності, з однаковим гідромодулем, ПМХЕ і ЦМХЕ показують схожі результати щодо зміни коефіцієнту світлопропускання і становлять 26,2 \% та 28 \% відповідно. Трохи вищий показник ЦМХЕ можна обгрунтувати тим, що кількість екстрагенту була трохи вища за ПМХЕ. Кінцеве значення сухих речовин у отриманих екстрактах на ПМХЕ та ЦМХЕ становить 2,45 г/л та 2,35 г/л відповідно. Екстракти отримані даним методом відрізняються ярко вираженим ароматом дубової деревини, колір світло-коричневий.

Слід відмітити, що при використанні в якості екстрагенту етилового спирту з більшою концентрацією 72 об.\%., коефіцієнт світлопропускання значно нижчий. В серіях 9 - 11 проведено дослідження можливості альтернативного використання дубової деревини у виноробній промисловості. Пропонується інноваційна технологія виробництва високоекстрактивних вин з використання МХ технологій та дубової деревини. Параметри процесу екстрагування представлені в таблиці 1. Термограми процесів отримання високоектсрактивних вин наведені на рис. 11.

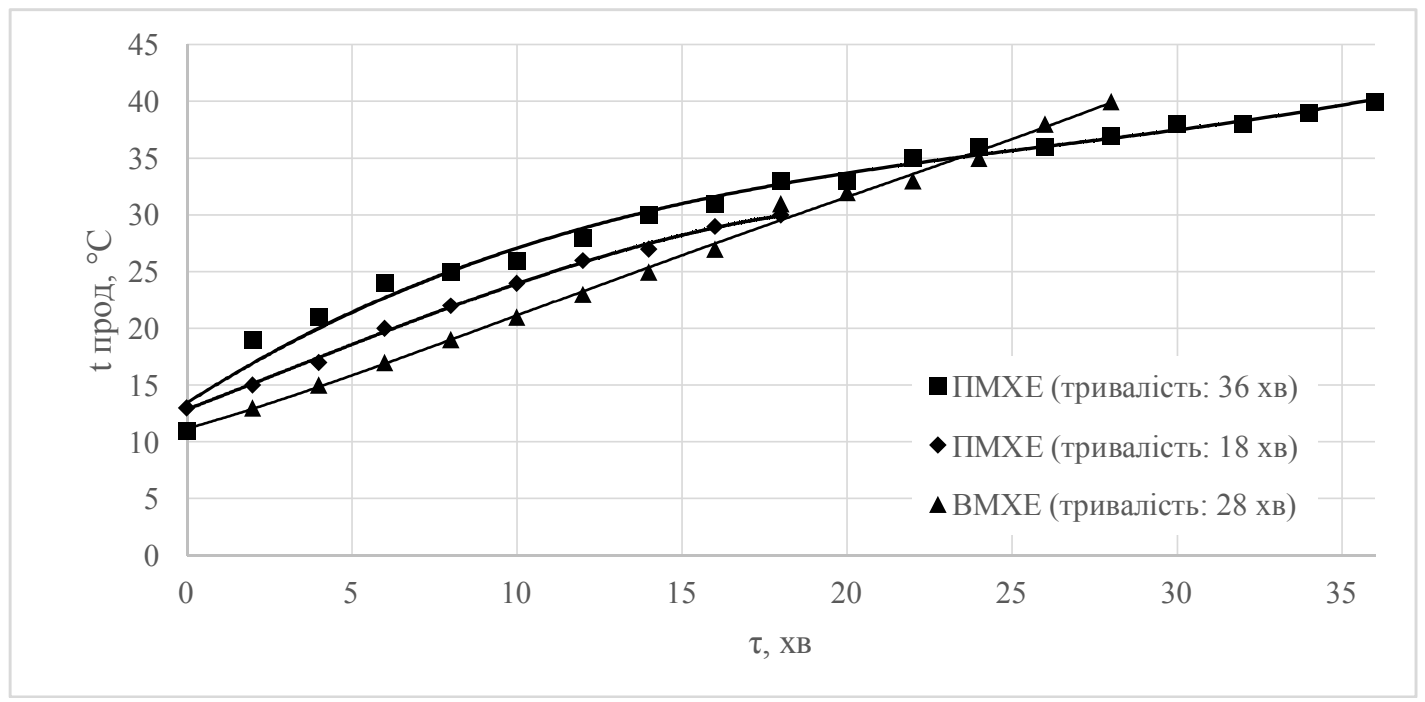

Рис. 11 - Порівняння термограм процесів отримання високоекстрактивних вин

Аналіз рис 11., показує, що температура у всіх експериментах підвищується рівномірно і набирають приблизно однакову температуру в близьких на графіку точках. Витрати електроенергії для ПМХЕ (час 36 хв.) складають 0,116 кВт·год, для ПМХЕ (час 18 хв.) - 0,055 кВт·год, для ВМХЕ (час 28 хв.) складають 0,07 кВт·год.

Органолептична характеристика вин. Після закінчення процесу екстрагування дубових кубиків вином, отриманим винам дали охолонути і потім провели дегустацію. Всі зразки отриманих вин не мали ярко вираженого аромату дуба, їхній смак мав ноти увареності. Надалі винам дали можливість відпочити після екстрагування для асиміляції екстрактивних речовин з дуба у вині. Вина витримували у скляних пляшках приблизно 2 тижні. Після закінчення терміну була проведена повторна дегустація. 
Перший зразок вина (ПМХЕ, час 36 хв.) мав виражений тонкий ненав'язливий аромат дуба та ванілі, смак приємний, відчуваються дубильні речовини, екстрактивність, спостерігався характерний тон витримки, з'явилася округлість. Але був присутній легкий тон термообробки. Початковий зразок вина не мав вищезазначених характеристик. Другий зразок вина (ПМХЕ, час 16 хв) мав трохи кращу ароматику вина, трохи більше танінності, сильніша терпкість, загалом другий зразок, менш гармонійний у порівнянні 3 першим зразком. Тому було рекомендовано до подальшої витримки. Третій зразок (BMXЕ, час 28 хв) теж мав тони дубової бочки, не гармонійний, відсутній так званий стрижень вина. Імовірно, це пов'язано $з$ тим, що процес проводився у вакуумі, де дубова деревина знаходилася в об'ємі вина, і вино поглинало більшу частину МХ енергії, через що спирт з вина почав випаровуватися і завдяки зворотному холодильнику накопичувався на ньому і стікав у загальний об'єм вина з кубиками назад. I саме цей процес міг зруйнувати так званий стрижень вина, через що воно і відчувалось негармонійним.

Висновки. В результаті комплексних експериментальних досліджень доказана гіпотеза о можливості отримання поліекстрактів при використанні розчинника із полярними молекулами та в умовах мікрохвильового поля. За косвеними показниками (такими як: температура, концентрація екстракту, енергетичні витрати) підтверджено дію механодифузійного ефекту. Вихід цільових компонентів у мікрохвильових екстрактоpax в 2,5...5 разів вищий, ніж у традиційних при знижені енергетичних витрат у 1,5...2 рази. Визначено енергетичні переваги циркуляційного екстрактору із імпульсним підведенням мікрохвильової енергії. При цьому гарантується висока якість продукту, можливість отримання поліекстрактів.

Мікрохвильові екстрактори мають перспективи в технологіях переробки рослинної сировини для отримання фіто екстрактів лікарських препаратів. Ефективні при виробництві поліекстрактів із дубової деревини. Спроможні вирішувати проблемні питання у виноробній індустрії, при створені високо екстрактивних вин, бренді. Серед конструкцій наразі привабливими є плівкові та циркуляційні екстрактори. Такі екстрактори мають переваги щодо отримання якісних поліекстрактів 3 дубової деревини, з більш повним вилученням компонентів та перспективами промислового впровадження.

\section{References}

1. Burdo, O. H., Ruzhytskaia, N. V., Makarenko, T. A., \& Malashevych, S. A. (2015). Kontsentrirovaniye ekstraktov stevii v mikrovolnovoy vakuum-vyparnoy ustanovke [Concentration of stevia extracts in a microwave vacuum evaporation plant]. Scientific Works, 47, 67-70 (in Russian). https://doi.org/doi.org/10.15673/swonaft.v1i47.401

2. Poperechnyi, A. M. (2014). Protsesy i aparaty kharchovykh vyrobnytstv [Processes and apparatuses of food production]. In O. V. Bohomolova, \& V. I. Maiak (eds.), Kharkiv: Svit Knyh (in Ukrainian).

3. Rakhmankulov, D. L., Shavshukova, S. Yu., \& Vykhareva, Y. N. (2008). Prymenenye mykrovolnovoho yzluchenyia $\mathrm{v}$ pyshchevoi otrasly [Application of microwave radiation in the food industry]. Bashkyrskyi Khymycheskyi Zhurnal, 15(1), 1-3 (in Russian).

4. Puligundla, P., Abdullah, S. A., Choi, W., Jun, S., Oh, S., \& Ko, S. (2013). Potentials of Microwave Heating Technology for Select Food Processing Applications - a Brief Overview and Update. Journal of Food Processing \& Technologies, 4(11), 1-9. https://doi.org/10.4172/2157-7110.1000278

5. Burdo, O. G., Syrotyuk, I. V, Alhury, U., \& Levtrinska, J. O. (2018). Microwave Energy as an Intensification Factor in the Heat-Mass Transfer and the Polyextract Formation. Problems of the Regional Energetics, 36(1), 58-71. https://doi.org/10.5281/zenodo.1217259

6. Romancova, N. A., Mandzhigoladze, T. YU., \& Kuznecova, L. S. (2015). Resheniye problemy resursosberezheniya pri poluchenii ekstrakta zhidkogo iz sbora lekarstvennogo rastitel'nogo syr'ya [Solving the problem of resource saving when obtaining a liquid extract from the collection of medicinal plant raw materials]. Izvestiya Samarskogo Nauchnogo Centra Rossijskoj Akademii Nauk, 17(5), 188-192 (in Russian).

7. Oboturova, N. P., Sudakova, N. V., Kokoeva, V. S., \& Zajcev, A. S. (2013). Primenenie ekstraktov rastitel'nogo syr'ya pri proizvodstve pishchevyh produktov [The use of extracts of plant raw materials in the production of food products]. Pishchevaya Promyshlennost', 6, 48-50 (in Russian).

8. Georgiesh, E.V. (2015) Intensifikaciya processa teplomassoperenosa pri ekstragirovanii biologicheski aktivnyh veshchestv iz rastitel'nyh materialov v usloviyah dejstviya mikrovolnovogo polya [Intensification of the heat and mass transfer process during the extraction of biologically active substances from plant materials under the action of a microwave field]. dis. kand., tekhn. nauk, ONAPT (in Russian).

9. Ermolaeva, E. O., \& Poznyakovskij, V. M. (2004). Razrabotka novoy promyshlennoy tekhnologii sukhikh rastitel'nykh ekstraktov[Development of a new industrial technology of dry plant extracts]. Sovremennyye naukoyemkiye tekhnologii, 6, 10-13 (in Russian).

10. Chueshov V.I., Gladuh E.V, Sajko I.V. et al. (2014) Tekhnologiya lekarstv promyshlennogo proizvodstva [Technology of medicines of industrial production]. Vol. 1. Vinnytsya: Nova Kniga (in Ukrainian).

11. Kalla, A. M., \& Devaraju, R. (2017). Microwave energy and its application in food industry: A reveiw Microwave energy and its application in food industry: A reveiw. Journal of Dairying, Foods \& Home Sciences. https://doi.org/10.18805/ajdfr.v0iOF.7303 


\title{
KINETICKS AND ENERGETICS OF EXTRACTION PROCESSES OF OAK WOOD IN ELECTROMAGNETIC FIELD
}

\author{
Akimov O.V., postgraduate student, Molchanov M.Y., graduate student, Voytenko A.K., Ph.D., associate \\ professor, Burdo O.G., Dr. Sci. Tech., professor \\ Odesa national academy of food technologies, Odesa
}

\begin{abstract}
New and perspective method of extraction with usage of electromagnetic field is reviewed. The article provides advantages of using extraction in electromagnetic field over traditional methods of extractions. The main problem of traditional extraction technologies are retrieval incompleteness of targeted components and duration of the process. The article considers possibilities and perspectives of using oak wood extracts in different industries. The main scientific and technical contradiction of extraction was formulated. New hypothesis of extraction in electromagnetic field was proposed. The article provides methodology of experimental research, detailed description of devices which were used in the study and parameters of conducted experiments where water was used as extractant. Thermograms, changing of light transmission index and electricity consumption of all five series of experimental research are given in the article. Concentration comparison of dry matter in final extracts are given. The series of experimental research of extraction of oak wood using ethyl alcohol as extractant were also conducted, the parameters of research, thermograms, changing of light transmission index, electricity consumption and comparison of concentrations of dry matter are represented in the article. Article offers new innovative technology of highly extractive wines based on usage of microwave technologies and oak wood as an alternative to wines aging in oak barrels. Short organoleptic descriptions of obtained extracts and wines are given. The hypothesis about obtaining polyextracts by using polar extractants in electromagnetic field was proved. The mechanodiffusion effect was confirmed. It was confirmed that extraction of targeted components in MW extractors is 2,5...5 times higher than in traditional methods of extraction, energy consumption is 1,5 ...2 times lower than in traditional ones. It was defined that film and circulating extractors have advantages in obtaining high quality polyextracts from oak wood with higher rate of extraction of targeted components and have perspectives of industry application.
\end{abstract}

Key words: extraction, electromagnetic field, kinetics, energetics, oak wood.

\section{Список використаної літератури}

1. Бурдо, О. Г., Ружицкая, Н. В., Макаренко, Т. А., та ін. Концентрирование экстрактов стевии в микроволновой вакуум-выпарной установке. Наукові праці. 2015. Том 47. С. 67-70.

2. Поперечний, А. М. Процеси і апарати харчових виробництв: / за ред., О. В. Богомолова, В. І. Маяк. Харків: Світ Книг, 2014. 495с.

3. Рахманкулов, Д. Л., Шавшукова, С. Ю., Вихарева, И. Н. Применение микроволнового излучения в пищевой отрасли. Башкирский химический журнал. 2008. Том 15, №. 1. С. 1-3.

4. Puligundla, P., Abdullah, S. A., Choi, W., та ін. Potentials of Microwave Heating Technology for Select Food Processing Applications - a Brief Overview and Update. Journal of Food Processing \& Technologies. 2013. Vol. 4, No. 11.p. 1-9.

5. Burdo, O. G., Syrotyuk, I. V, Alhury, U., et. al. Microwave Energy as an Intensification Factor in the HeatMass Transfer and the Polyextract Formation. Problems of the Regional Energetics. 2018. Vol. 36, No. 1. C. 58-71.

6. Романцова, Н. А., Манджиголадзе, Т. Ю., Кузнецова, Л. С. Решение проблемы ресурсосбережения при получении экстракта жидкого из сбора лекарственного растительного сырья. Известия Самарского научного иентра Российской академии наук. 2015. Том. 17, №. 5. С. 188-192.

7. Оботурова, Н. П., Судакова, Н. В., Кокоева, В. С., та ін. Применение экстрактов растительного сырья при производстве пищевых продуктов. Пищевая промышленность. 2013. Том. 6. С. 48-50.

8. Георгиеш Е.В. Интенсификация процесса тепломассопереноса при экстрагировании биологически активных веществ из растительных материалов в условиях действия микроволнового поля: дис. канд., техн. наук. Одесса, 2015. - 185 с.

9. Ермолаева, Е. О., Позняковский, В. М. Разработка новой промышленной технологии сухих растительных экстрактов. Современные наукоемкие технологии. 2004. №. 6. С. 10-13.

10. Технология лекарств промышленного производства: учебник для студ. высш. учеб. завед.: перевод с укр. в 2 ч. Ч. 1 ; перевод с укр. яз. / В.И. Чуешов, Е.В Гладух, И.В. Сайко и др. Винница: Нова Книга, 2014. 696c.

11. Kalla, A. M., Devaraju, R. Microwave energy and its application in food industry : Journal of dairying, foods $\&$ home sciences. 2017.

Отримано в редакцію 10.03.2021

Прийнято до друку 26.06.2021
Received 10.03.2021

Approved 26.06.2021 